\title{
Hydro-environmental pollution of Turag river in Bangladesh
}

\author{
J. B. Islam ${ }^{1}$, S. Akter ${ }^{1}$, A. C. Bhowmick ${ }^{2}$, M. N. Uddin ${ }^{3}$ and M. Sarkar ${ }^{3 *}$ \\ ${ }^{I}$ Institute of National Analytical Research and Service, Bangladesh Council of Scientific and Industrial Research, \\ Dhaka-1205, Bangladesh \\ ${ }^{2}$ Department of Chemistry, Mawlana Bhashani Science and Technology University, Tangail-1902, Bangladesh \\ ${ }^{3}$ Pulp and Paper Research Division, BCSIR Laboratories, Dhaka, Dhaka-1205, Bangladesh
}

\begin{abstract}
The pollution due to minerals and anions in surface water and their settlement tendency on sediment of the Turag river has been studied. Higher concentration of potassium and phosphate ion in surface water and similar deposition on sediment has been recorded. The observed average concentration of $\mathrm{Na}, \mathrm{K}, \mathrm{Cl}^{-}, \mathrm{PO}_{4}{ }^{3-}$ in surface water and in surface sediment was $22.10,13.20,108.50,17.80 \mathrm{mg} / \mathrm{L}$ and $1359.07,2526.10,37.50,31.76 \mathrm{mg} / \mathrm{kg}$, respectively. This high concentration of minerals and anions in surface water and sediments indicates that hidro-environment of the Turag river is badly affected.The minerals and ions are strongly correlated $(r=0.99)$ which implies that they come from similar sources and forcefully added to the river in a regular basis. Principal component analysis reveals that only one principal component is covering more than $99 \%$ of cumulative variance. There are very few variations of parameters in the principal component to indicate that all parameters exert similar effect on hydro-environment and are contributing to deteriorate the ecological balance.These are supported by dendrogram analysis.
\end{abstract}

Received: 26 November 2017
Revised: 26 December 2017

Accepted: 31 January 2018

DOI: http://dx.doi.org/10.3329/bjsir.v53i3.38261
Keywords: Minerals; Anions; Pollution; Principal component analysis; Cluster analysis

\section{Introduction}

Green environment is one of the prime concerns for safe future generation. Water is one of the prime components of our environment. In near future the universe will face acute curse of fresh water due to pollution. Surface water pollution, from the last couple of decades, is drawing more attention as it is vulnerable for pollution with world development (Islam et al., 2015). Bangladesh has unplanned industries which are not operated according to proper effluent treatment strategies and untreated or partially treated effluent has been throwing into the nearby water body which demolishes the aquatic environment (Sarkar et al., 2017). River and their catches are very important to protect hydro-environmental balance through which hydrochemistry, ecosystem and natural heritage are saved. The hydrochemistry of water body is affected by many factors like anthropogenic, natural and manmade activities. Among these factors manmade activities are very prominent. From manmade activities industrial effluents, agricultural runoffs, land runoffs, municipal wastes, hospital wastes and mine pollutions are the most common factors for influencing biogeochemistry of water body. The government of Bangladesh has focused on industrial development from the last decades for improving living standard of mass people and keeping a constant GDP growth more than $7 \%$. Therefore, the extended use of water for industrial purpose exerts pressure on surface water and thereby pollutes water resources as proper effluent treatment is not imposed.

Fresh water, one of the vital elements of the earth, has a strong correlation with all kinds of lives for sustaining (Sarkar et al., 2015). The strategies taken in Bangladesh for saving rivers from pollution have completely failed against recent industrial development (Sarkar et al., 2016). This problem is intensified by unplanned urbanization, unlawful industrialization, unscientific land use and lack of public awareness. Knowledge of hydrochemical characteristic is more important to understand the surface water quality, ecosystem, biogeochemical behavior of water body, hydrochemistry and suitability of life cycle in water body.

\footnotetext{
*Corresponding author e-mail: akash.mamon@gmail.com
} 
Over pressure on ground water with population density from last couple of decades has drawn more attention to surface water for daily use like drinking, household use, irrigation and industrial supply.

The Turag is an important river in Bangladesh flowing through the north side of Dhaka mega city and itemize Gazipur district. Rapid industrial growth has occurred on the bank city Gazipur at Tongi arena under the Bangladesh Master Plan-1959. A variety of industries like garments, textile, spinning, jute, metal industries, tobacco, pharmaceuticals, chemical, pesticides, food processing, tanneries and many more are located in this industrial zone. The rhythm, however of waste disposal and waste management system has not kept pace with this industrial growth.Therefore, the Turag has been a dumping station for this industrial zone. Beside this unplanned construction and unscientific use of agricultural land has been continuing. The construction materials and residual pesticide as well as fertilizes have been mixed into the Turag river water. Municipal wastes from Gazipur City Corporation are intensifying this pollution. Recently, the government of Bangladesh takes a master plan to protect the peripheral rivers of Dhaka city. Under this plan, government prescribed mandatory effluent treatment plant for the industries. As a part of that plan, the Turag has been emancipated from illegal possession and dredged for circular waterway of Dhaka city communication and recreation. The acrid smell and pollution is one of the major obstacles for the suitable environment and ecosystem of Turag river. Suitability of surface water for household, industrial, irrigational use and recreational use is determined by its hydro-chemical characteristics.

A lot of works have been reported on Turag river. Zakir et al. (2006), Banu et al. (2013), Ahmed et al. (2016) and Sarkar et al. (2016) investigated the physicochemical parameters and heavy metal pollution. However, minerals and ionic pollution in surface water and sediment have not been focused significantly in any of the previous works. In this study, we aim at monitoring the mineral and ionic pollution in surface water and sediment to assess the hydrochemistry, ecosystem for understanding hydrological balance of Turag river. Finally, we analyzed the data for correlation, principal component analysis and cluster analysis for better understanding the inter connectivity of the minerals and ions.

\section{Materials and methods}

Study Area

The Turag river is one of the major rivers of Bangladesh which is the upper tributary of the Buriganga river and originated from the Bangshi river in Kaliakair Upozila. Truag river is a commercially important and navigable river all year round. According to literature, the Turag is facing huge pollution problem from industrial and household sources. Therefore, we select this river as our study area in industrial vicinity. Samples were collected from the three preselected untreated industrial effluent discharged arena of the Turag river (Fig. 1) during Dry (February) and Wet (June) season in 2015. The sampling stations were Dhaka dyeing (SS-1), Hossain dyeing (SS-2) and Zaber \& Zubair Fabrics (SS-3).

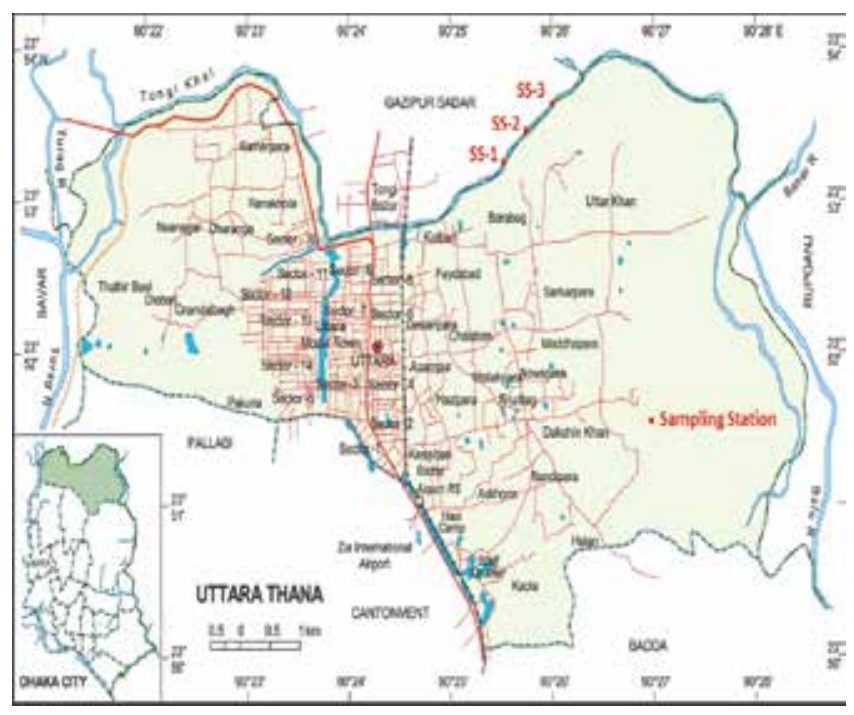

Fig. 1. Untreated effluent discharged into the Turag river

\section{Sample collection and preparation}

Surface water samples were collected from $60 \mathrm{~cm}$ deep from the surface and sediment samples were collected from the undisturbed top $5 \mathrm{~cm}$ layer.The collected samples were transferred carefully to the laboratory as soon as possible. Water samples were preserved in refrigerator for preventing microbial decomposition of different materials present in the samples. Before analysis samples were taken to the normal temperature. Sediment samples were sun dried first and then dried in oven at 50 ${ }^{\circ} \mathrm{C}$. After drying, sediment samples were ground in a motor and sieved for homogeneity. Finally, $1.0 \mathrm{~g}$ of each sample was digested using $10.0 \mathrm{~mL}$ of concentrated $\mathrm{HNO}_{3}$ and aliquot portion of water on a hot plate till to dryness. After that $5.0 \mathrm{~mL}$ of concentrated $\mathrm{HClO}_{4}$ was added and then digestion was continued. The obtained solution was diluted to $100 \mathrm{~mL}$ with double distilled water. 


\section{Experimental}

Samples were analyzed according to the standard procedure (APHA, 1915). The samples were digested before analysis. An aliquot of $100 \mathrm{~mL}$ of each sample was taken into a 250 $\mathrm{mL}$ of pyrex beaker. To acidify the sample, $1 \mathrm{M}$ concentrated $\mathrm{HCl}(9 \mathrm{~mL})$ as well as $1 \mathrm{M}$ concentrated nitric acid $(3 \mathrm{~mL})$ was added in the beaker. The solution was carefully heated on a sand bath near to dryness into the fume hood. After cooling to the room temperature, deionized water was added to the sample up to the mark of a $100 \mathrm{~mL}$ flask. The solution was filtered and the filtrate was collected in a screw cap plastic tube. Digested samples were used for every analysis. The Atomic Absorption Spectrometer (AAS) was calibrated for all the metals by running different concentration of standard solutions. Sodium and potassium were measured by Flame Photometer (PFP7, JENWAY), while calcium and magnesium were analyzed by AAS(AA240FS, VARIAN). A $\mathrm{N}_{2} \mathrm{O}$-air-acetelene flame was used for calcium analysis and air-acetelene flame was used for magnesium analysis. The anions, $\mathrm{F}^{-}, \mathrm{Cl}^{-}, \mathrm{Br}^{-}, \mathrm{NO}_{2}^{-}, \mathrm{NO}_{3}^{-}$and $\mathrm{SO}_{4}{ }^{2-}$ ware evaluated by Ion Chromatograph (LC-10AD, Shimadzu, Japan) and $\mathrm{PO}_{4}^{2-}$ was measured spectrophotometrically by a UV Spectrophotometer (UV-1650 PC, Shimadzu).

\section{Data Analysis}

The obtained data were correlated statistically. Principal Component Analysis (PCA) and Cluster Analysis (CA) have also been done. Hierarchical Cluster Analysis has been used here to see the coexistence of minerals and anions in the surface water and sediments in the river and the output is expressed through Dendrogram. All analyses were performed by Statistical Package for Social Sciences software (SPSS 16).

\section{Results and discussion}

Water of the Turag river was dark and pungent during the sampling period. Lot of floating materials was observed on the surface of the river. This study emphasizes on the observation of minerals and anionic concentration in the economically and environmentally impacted Turag river. The source of over concentrated pollutant is by and large industrial. Beside this, agricultural runoff, municipal wastes and anthropogenic sources enhance the pollution level. The turbid and dark water is not suitable for sunlight penetration which disturbs the photosynthesis of aquatic plants. Therefore, the carbon dioxide will increase in the water body and consequently, increases the $\mathrm{pH}$ level.The colored water discharged from dying industries and other sources, captures more heat which is one of the causes of increased temperature in water body. As a consequence, the ecosystem is distressed and the balance in hydrochemistry and biogeochemistry is disturbed.The concentration of minerals and ions detected in surface water and surface sediment is furnished in Table I. In both surface water and surface sediment the concentration of minerals and ions was higher during dry season and diluted in wet season.

The concentration of $\mathrm{Na}$ is surface water and sediment ranged from $13.2-32.3 \mathrm{mg} / \mathrm{L}$ with average value 22.1 $\mathrm{mg} / \mathrm{L}$ and $1008.4-1829.2 \mathrm{mg} / \mathrm{kg}$ with average value $1359.07 \mathrm{mg} / \mathrm{kg}$, respectively. The sampling point SS-3 shows higher concentration of $\mathrm{Na}(32.3 \mathrm{mg} / \mathrm{L})$ for surface water in dry season and the deposition on sediment is also high $(1829.2 \mathrm{mg} / \mathrm{kg})$. However in surface water, the concentration of $\mathrm{Na}$ is within the permissible limit (200 $\mathrm{mg} / \mathrm{L})$ by WHO (2008). Main source of $\mathrm{Na}$ in the river water and in sediment may be the untreated or partially treated industrial effluent which is dumped into the river. Different types of sodium salt are used by industries (mainly tannery, dying) for their process run. If sodium concentration is higher as combined with chlorine and sulfate then the water would not be suitable for irrigational use (Azizullah et al., 2011). Sodium polluted irrigated water makes the soil puddling and therefore, decrease the water intake capability and becomes hard in which makes seed germination difficulties (Raza et al., 2007). Higher concentration of sodium may impose osmotic stress on the aquatic biota (Raza et al., 2007). Therefore, the population of biota may be decreased which makes a lame ecosystem. The concentration of $\mathrm{K}$ in surface water and sediment is tabulated in the range of 7.59-20.36 $\mathrm{mg} / \mathrm{L}$ and 1723.68-3420.14 $\mathrm{mg} / \mathrm{kg}$, respectively. Potassium concentration was much higher in sediment than in surface water which means that $K$ is more like to settle down. The permissible limit of $\mathrm{K}$ in drinking water is $12 \mathrm{mg} / \mathrm{L}$ by European Community (EC, 1986). According to $\mathrm{EC}$ the Water contaminated by $\mathrm{K}$ could not be used for drinking, cooking and household purpose. Concentration of $\mathrm{Mg}$ in surface water and sediment is documented in the range of $2.0-5.7 \mathrm{mg} / \mathrm{L}$ and 475.7-932.5 $\mathrm{mg} / \mathrm{kg}$, respectively. The range of $\mathrm{Ca}$ in surface water as well as in sediment is recorded as 11.2-25.5 mg/Land 734.7-1382.7 mg/kg, respectively. Sampling point SS-2 shows the highest concentration of $\mathrm{Ca}$ in surface water $(25.5 \mathrm{mg} / \mathrm{L})$ and that is expected in sediment (1382.5 mg/kg). According to WHO (2008) permissible limit of $\mathrm{Mg}$ and $\mathrm{Ca}$ is $100 \mathrm{mg} / \mathrm{L}$ and 150 $\mathrm{mg} / \mathrm{L}$, respectively. With respect to the concentration of 
Table I. Minerals and ions in the surface water and sediment of Turag river

\begin{tabular}{|c|c|c|c|c|c|c|c|c|c|}
\hline \multicolumn{10}{|c|}{ Concentrations $(\mathrm{mg} / \mathrm{L})$ of minerals and anions in water } \\
\hline \multirow[t]{2}{*}{ Species } & \multicolumn{3}{|c|}{ Dry (Feb) } & \multicolumn{3}{|c|}{ Wet (Jun) } & \multirow[t]{2}{*}{ Average } & \multirow[t]{2}{*}{ Min. } & \multirow[t]{2}{*}{ Max. } \\
\hline & SS-1 & SS-2 & SS-3 & SS-1 & SS-2 & SS-3 & & & \\
\hline $\mathrm{Na}$ & 29.517 & 30.118 & 32.284 & 13.211 & 13.250 & 14.222 & 22.10 & 13.211 & 32.284 \\
\hline $\mathrm{Mg}$ & 5.500 & 5.507 & 5.685 & 2.011 & 2.003 & 2.472 & 3.86 & 2.003 & 5.685 \\
\hline $\mathrm{K}$ & 16.815 & 18.569 & 20.362 & 7.591 & 7.825 & 8.015 & 13.20 & 7.591 & 20.362 \\
\hline $\mathrm{Ca}$ & 23.138 & 25.532 & 25.035 & 11.22 & 11.983 & 12.61 & 18.25 & 11.22 & 25.532 \\
\hline $\mathrm{F}^{-}$ & 0.500 & 0.560 & 0.501 & 0.025 & 0.037 & 0.079 & 0.28 & 0.025 & 0.560 \\
\hline $\mathrm{Cl}^{-}$ & 125.39 & 132.845 & 147.368 & 80.741 & 81.259 & 83.501 & 108.52 & 80.741 & 147.368 \\
\hline $\mathrm{Br}^{-}$ & 1.000 & 1.000 & 1.102 & 0.520 & 0.551 & 0.563 & 0.79 & 0.520 & 1.102 \\
\hline $\mathrm{NO}_{2}^{-}$ & 1.000 & 1.111 & 1.250 & 0.218 & 0.245 & 0.266 & 0.68 & 0.218 & 1.250 \\
\hline $\mathrm{NO}_{3}^{-}$ & 3.000 & 4.870 & 4.290 & 1.005 & 1.150 & 1.207 & 2.60 & 1.005 & 4.870 \\
\hline $\mathrm{SO}_{4}^{2-}$ & 145.68 & 148.921 & 143.80 & 101.205 & 102.552 & 102.892 & 128.50 & 101.205 & 148.921 \\
\hline $\mathrm{PO}_{4}^{3-}$ & 22.66 & 25.328 & 26.103 & 9.897 & 11.285 & 11.598 & 17.81 & 9.897 & 26.103 \\
\hline \multicolumn{10}{|c|}{ Concentrations $(\mathrm{mg} / \mathrm{kg})$ in Sediment } \\
\hline $\mathrm{Na}$ & 1516.825 & 1732.523 & 1829.218 & 1008.459 & 1032.111 & 1035.278 & 1359.07 & 1008.459 & 1829.218 \\
\hline $\mathrm{Mg}$ & 897.416 & 867.911 & 932.531 & 475.666 & 478.967 & 513.005 & 694.25 & 475.666 & 932.531 \\
\hline $\mathrm{K}$ & 3245.477 & 3278.387 & 3420.143 & 1734.581 & 1723.684 & 1754.302 & 2526.10 & 1723.684 & 3420.143 \\
\hline $\mathrm{Ca}$ & 1368.453 & 1382.547 & 1375.981 & 734.726 & 814.451 & 767.655 & 1073.97 & 734.726 & 1382.547 \\
\hline $\mathrm{F}^{-}$ & 4.60 & 5.208 & 5.222 & 1.296 & 1.543 & 1.556 & 3.24 & 1.296 & 5.222 \\
\hline $\mathrm{Cl}^{-}$ & 42.85 & 42.89 & 45.702 & 28.712 & 32.420 & 32.573 & 37.52 & 28.712 & 45.702 \\
\hline $\mathrm{Br}^{-}$ & 1.000 & 1.000 & 1.100 & 0.500 & 0.552 & 0.555 & 0.78 & 0.500 & 1.100 \\
\hline $\mathrm{NO}_{2}^{-}$ & 2.04 & 3.10 & 3.33 & 1.005 & 1.016 & 1.112 & 1.93 & 1.005 & 3.330 \\
\hline $\mathrm{NO}_{3}^{-}$ & 107.94 & 108.23 & 108.34 & 74.283 & 77.867 & 75.694 & 92.06 & 74.283 & 108.34 \\
\hline $\mathrm{SO}_{4}^{2-}$ & 1159.06 & 1168.25 & 1258.623 & 735.665 & 762.537 & 792.108 & 979.37 & 735.665 & 1258.623 \\
\hline $\mathrm{PO}_{4}^{3-}$ & 37.97 & 39.501 & 40.572 & 23.829 & 22.843 & 25.882 & 31.77 & 22.843 & 40.572 \\
\hline
\end{tabular}


$\mathrm{Mg}$ and $\mathrm{Ca}$, surface water of Turag river is safe for different daily uses. Magnesium is the key component of chlorophylla which plays an important role in ecosystem. Higher concentration of $\mathrm{Mg}$ makes hard water which creates difficulties in household washing. Like $\mathrm{Mg}, \mathrm{Ca}$ also creates problem in household washing. Long time ingestion of excess Ca may cause hypercalcemia, urinary tract calculi, calcification in soft tissues like kidneys and in arterial walls and suppression of bone remodeling (Heaney et al., 1982).

In surface water and surface sediment the concentration of fluoride ion ranged from $0.025-0.6 \mathrm{mg} / \mathrm{L}$ and 1.3-5.2 $\mathrm{mg} / \mathrm{L}$, respectively. The source of fluoride is of anthropogenic character. Besides this, pesticide, fertilizer, industrial wastes and agricultural runoff enhance the concentration of fluoride in wetland. Fluoride is an essential element for human, plays an important role for teeth and bones structure. However, more than 1.5 $\mathrm{mg} / \mathrm{L}$ intake of fluoride causes dental and skeletal fluorosis (CDCP, 1999). The chloride ion concentration in surface water and sediment of Turag River ranges from
$80.74-137.37 \mathrm{mg} / \mathrm{L}$ and $28.71-45.70 \mathrm{mg} / \mathrm{L}$, respectively. The permissible limit of chlorine in surface water is 250 $\mathrm{mg} / \mathrm{L}$ (WHO, 2008). The sources of chloride in surface water and sediment might be chlorinated pesticides and wastes from industries. The concentration of bromide ion in surface water and surface sediment ranged from $0.52-1.1 \mathrm{mg} / \mathrm{L}$ and $0.5-1.1 \mathrm{mg} / \mathrm{L}$, respectively which mean that $\mathrm{Br}$ has fewer tendencies to precipitate.

The concentration of $\mathrm{PO}_{4}^{3-}$ in surface water and surface sediment of Turag river is in the range of $9.9-26.1 \mathrm{mg} / \mathrm{L}$ and $22.8-40.6 \mathrm{mg} / \mathrm{kg}$, respectively. Phosphate ion is sparingly soluble in water and is adsorbed with clay particles and precipitates as $\mathrm{Fe}, \mathrm{Al}$ and $\mathrm{Ca}$ compounds. The concentration of phosphate in surface water is higher than the safe level $(6 \mathrm{mg} / \mathrm{L})$ suggested by European Community (1986). The sources of $\mathrm{PO}_{4}^{3-}$ in Turag river may be fertilizer and industrial wastes. The range of sulfate ion in surface water and surface sediment of the Turag river is tabulated as 101.2-148.9 $\mathrm{mg} / \mathrm{L}$ and $735.7-1258.6$ $\mathrm{mg} / \mathrm{kg}$, respectively. Surface water of Turag river is till now nontoxic according to the WHO (2008)

Table II. Correlation among the minerals and ions

\begin{tabular}{|c|c|c|c|c|c|c|c|c|c|c|c|}
\hline Species & $\mathrm{Na}$ & $\mathrm{Mg}$ & $\mathrm{K}$ & $\mathrm{Ca}$ & $\mathrm{F}^{-}$ & $\mathrm{Cl}^{-}$ & $\mathrm{Br}^{-}$ & $\mathrm{NO}_{2}^{-}$ & $\mathrm{NO}_{3}^{-}$ & $\mathrm{SO}_{4}{ }^{2-}$ & $\mathrm{PO}_{4}{ }^{3}$ \\
\hline $\mathrm{Na}$ & 1 & & & & & & & & & & \\
\hline $\mathrm{Mg}$ & $0.994^{*}$ & 1 & & & & & & & & & \\
\hline K & $0.994^{*}$ & $0.999^{* *}$ & 1 & & & & & & & & \\
\hline $\mathrm{Ca}$ & $0.995^{*}$ & $0.999^{* *}$ & $0.999^{* *}$ & 1 & & & & & & & \\
\hline $\mathrm{F}^{-}$ & $0.913^{*}$ & $0.947^{* *}$ & $0.954^{* *}$ & $0.944^{* *}$ & 1 & & & & & & \\
\hline $\mathrm{Cl}^{-}$ & 0.248 & 0.273 & 0.285 & 0.263 & $0.510^{* *}$ & 1 & & & & & \\
\hline $\mathrm{Br}^{-}$ & 0.237 & 0.270 & 0.282 & 0.262 & $0.510^{* *}$ & 0.992 & 1 & & & & \\
\hline $\mathrm{NO}_{2}^{-}$ & $0.839^{*}$ & $0.838^{* *}$ & $0.849^{* *}$ & $0.834^{* *}$ & $0.942^{* *}$ & 0.706 & $0.687^{*}$ & 1 & & & \\
\hline $\mathrm{NO}_{3}^{-}$ & $0.992^{*}$ & $0.988^{* *}$ & $0.985^{* *}$ & $0.991^{* *}$ & $0.894^{* *}$ & 0.186 & 0.181 & $0.783^{* *}$ & 1 & & \\
\hline $\mathrm{SO}_{4}{ }^{2-}$ & 0.245 & 0.276 & 0.288 & 0.267 & $0.514^{* *}$ & 0.994 & $0.999^{* *}$ & $0.694^{*}$ & 0.189 & 1 & \\
\hline $\mathrm{PO}_{4}{ }^{3-}$ & 0.224 & 0.275 & 0.287 & 0.267 & $0.515^{* *}$ & 0.985 & $0.990^{* *}$ & $0.693^{*}$ & 0.188 & 0.993 & 1 \\
\hline
\end{tabular}

**Correlation is significant at the 0.01 level (2-tailed)

*Correlation is significant at the 0.05 level (2-tailed) 
guideline value for sulfate ion $(400 \mathrm{mg} / \mathrm{L})$ in drinking water. Concentration of nitrate ion in surface water and surface sediment ranged from 1.0-4.9 mg/L and 74.3-108.3 $\mathrm{mg} / \mathrm{kg}$, respectively as well as concentration of nitrite ion in surface water and surface sediment ranged from 0.2-1.2 $\mathrm{mg} / \mathrm{kgand} 1.0-3.3 \mathrm{mg} / \mathrm{kg}$, respectively. The possible sources of nitrogenous compounds ion are fertilizer, industrial effluent and human excreta (Weyer et al., 2001) and agriculture runoff. Excessive nitrate content in drinking water causes methemoglobinemia (blue baby) in infant (Murray and Christie, 1993). Nitrate is not itself carcinogenic but it forms N-nitroso compound in stomach which is carcinogenic (NAS,1981).

\section{Statistical analysis}

Interrelation among the parameters has been evaluated by Pearson's correlation (Table II). Pearson's correlation represents the dependency of one parameter to another. The results showed that the parameters are significant in the $p<0.01$ level.Table II shows that $\mathrm{Na}$ is significantly correlated with $\mathrm{Mg}, \mathrm{K}, \mathrm{Ca}, \mathrm{F}^{-}, \mathrm{NO}_{2}{ }^{-}$and $\mathrm{NO}_{3}^{-}(\mathrm{r}=0.99,0.99,0.99,0.91$, 0.84 and 0.99 , respectively). Furthermore, a significant positive correlation of $\mathrm{F}^{-}$with $\mathrm{NO}_{2}^{-}$and $\mathrm{NO}_{3}^{-}(\mathrm{r}=0.94$ and 0.89 ) is observed and a moderate correlation with $\mathrm{Cl}^{-} \mathrm{Br}-$, $\mathrm{SO}_{4}{ }^{2-}$ and $\mathrm{PO}_{4}{ }^{3-}(\mathrm{r}=0.51,0.51,0.51$ and 0.52 , respectively) is also noticed. $\mathrm{Br}$ is strongly correlated with $\mathrm{SO}_{4}^{2-}$ and $\mathrm{PO}_{4}^{3-}(\mathrm{r}$ $=0.99$ ). This strong and significant correlation reveals that the minerals and anions are forcefully added form the similar sources on regular basis. The correlation of $\mathrm{NO}_{3}{ }^{-}$with $\mathrm{SO}_{4}{ }^{2-}$ and $\mathrm{PO}_{4}{ }^{3-}$ is insignificant $(\mathrm{r}=0.18)$.

PCA furnished in Table III reflects that one component contains most of the metals and ions ( $99 \%)$. These findings reveal that the results of correlation are alien with PCA, which indicates the minerals and ions are forcefully added to the surface water and sediment of Turag river from the similar types of sources. After adulteration they remain in a group and settle down with similar trend and exert adverse effect on the ecosystem.

CA has also been applied for the measured parameters to find out the groups according to their similarities like their sources, distribution and chemical behavior. CA is a powerful method for analyzing data including outlier. The resulting data can be presented in a two dimensional plot called dendrogram (Fig. 2). Hierarchical CA has been performed to observe and predict the concomitance of minerals and anions in the surface water and sediments in the river. It is obtained from the Dendrogram of the cluster analysis that $\mathrm{Na}, \mathrm{Ca}, \mathrm{Mg}$ and $\mathrm{SO}_{4}^{-}$are in same cluster, $\mathrm{K}$ stand alone and rest of the anions considered in the study $\left(\mathrm{Br}, \mathrm{NO}_{2}^{-}, \mathrm{F}^{-}, \mathrm{PO}_{4}^{-}, \mathrm{NO}_{3}^{-}\right.$and

\section{Table III. Component Matrixa}

\begin{tabular}{cc}
\hline Species & Components \\
\cline { 2 - 2 } & 1 \\
\hline $\mathrm{Na}$ & 0.998 \\
$\mathrm{Mg}$ & 0.94 \\
$\mathrm{~K}$ & 0.997 \\
$\mathrm{Ca}$ & 0.997 \\
$\mathrm{~F}^{-}$ & 0.990 \\
$\mathrm{Cl}^{-}$ & 0.992 \\
$\mathrm{Br}^{-}$ & 0.996 \\
$\mathrm{NO}_{2}{ }^{-}$ & 0.999 \\
$\mathrm{NO}_{3}{ }^{-}$ & 0.962 \\
$\mathrm{SO}_{4}{ }^{2-}$ & 0.997 \\
$\mathrm{PO}_{4}{ }^{2-}$ & 0.997
\end{tabular}

Extraction method: Principal component analysis ${ }^{\mathrm{a}} 1$ components extracted

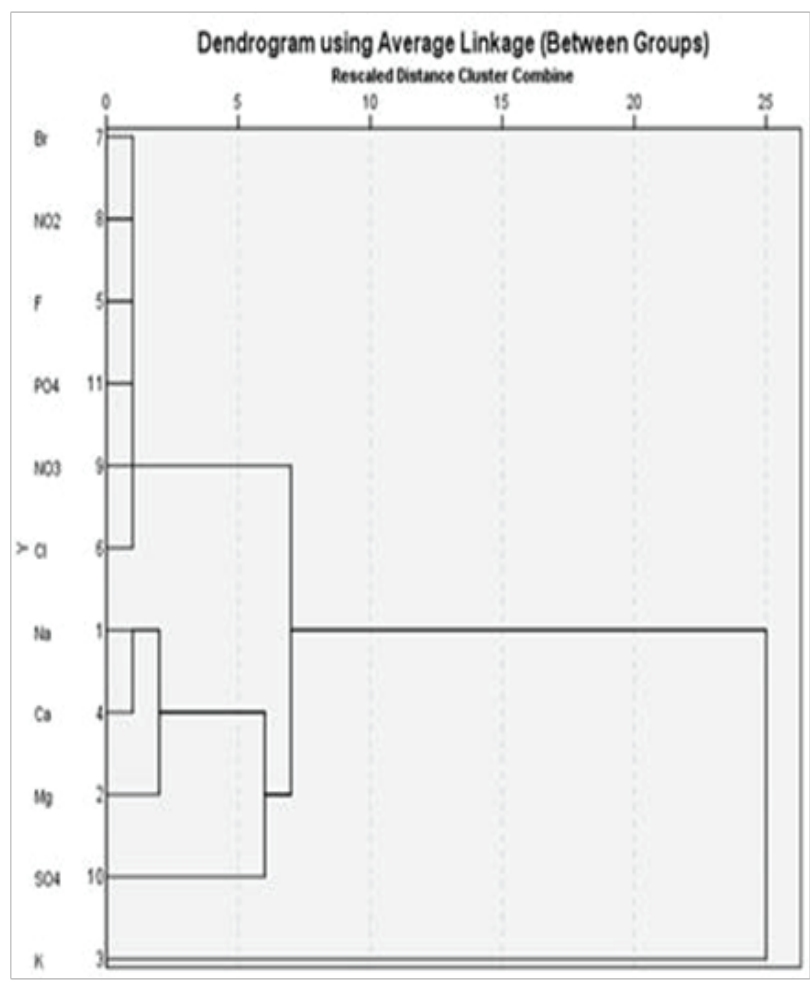

Fig. 2. Dandrogram from cluster analysis of minerals and anion 
$\mathrm{Cl}^{-}$) are in another cluster at distance 5 .

\section{Conclusion}

The concentration of minerals and ions is unexpectedly high in the surface water and surface sediment in the Turag. Concentration of $\mathrm{K}$ is relatively higher in sediment than in surface water as compared to other minerals which means that $\mathrm{K}$ is more likely to settle down. The sources of minerals and ions are similar and they exert similar level of effects on ecosystem which is predicted by the correlation, PCA and CA data. The ecosystem of Turag river is disturbed by the pollutants like color, minerals and anions generated from industries, household, municipal, land runoff and anthropogenic source. Therefore, the aquatic environment, hydrochemistry and biogeology are ruined day by day. A policy should be immediately taken by the respective authority to prevent the unethical discharge of effluent for protecting the hydro-environment of Turag river.

\section{Acknowledgement}

Authors are thankful to the Institute of National Analytical Research and Service (INARS), Bangladesh Council of Scientific and Industrial Research, for outstanding analytical support.

\section{References}

Ahmed KS, Rahman AKML, Sarkar M, Islam JB, Jahan IA, Moniruzzaman M and Bhoumik NC (2016), Assessment on the level of contamination of Turagriver at Tongi area in Dhaka. Bangladesh Journal of Scientific and Industrial Research 51(3): 193-202.

APHA (American Public Health Association) (1915), American Water Works Association, Water Pollution Control Federation, \& Water Environment Federation, Standard methods for the examination of water and wastewater, Vol. 2.

Azizullah A, Khattak MNK, Richter P and Häder DP (2011), Water pollution in Pakistan and its impact on public health - a review, Environment International 37(2): 479-497. DOI:10.1016/jenvint.2010.10.007

A Ayres (2015), Council on Foreign Relation, https://www.cfr.org/blog/imf-worried-about-banglade shs-growth.

Banu Z, Chowdhury MSA, Hossain MD and Nakagami KI (2013), Contamination and ecological risk assessment of heavy metal in the sediment of Turag River, Bangladesh: An index analysis approach. Journal of Water Resource and Protection 5(2): 239-248. DOI:10.4236/jwarp.2013.52024

CDCP (Center for Disease Control and Prevention) (1999), Achievements in public health, 1900-1999: fluoridation of drinking water to prevent dental caries, Morbidity and Mortality Weakly Report 48: 933-940.

EC (European Community) (1986), Guidelines for drinking water quality.

Heaney RP, Gallagher JC, Johnston CC, Neer R, Parfitt AM and Whedon GD (1982), Calcium nutrition and bone health in the elderly, The American Journal of Clinical Nutrition 36(5): 986-1013. DOI:10.1093/ajcn/36.5.986

Islam JB, Sarkar M, Rahman, AL and Ahmed KS (2015), Quantitative assessment of toxicity in the Shitalakkhya River, Bangladesh, The Egyptian Journal of Aquatic Research 41(1): 25-30. DOI:10.1016/j.ejar. 2015.02.002

Murray KF and Christie DL (1993), Dietary protein intolerance in infants with transient methemoglobinemia and diarrhea. The Journal of Pediatrics 122(1): 90-92. DOI:10.1016/soo22-3476 (05)83495-X

NAS (National Academy of Sciences) (1981), The Health Effects of Nitrate, Nitrite, and N-Nitroso Compounds, National Academy of Sciences Press, Washington DC.

Raza N, Niazi SB, Sajid M, Iqbal F and Ali M (2007), Studies on relationship between season and inorganic elements of KallarKahar Lake (Chakwal), Pakistan, Journal of Research (Science), 18: 61-68.

Sarkar M, Rahman AL, Islam JB, Ahmed KS, Uddin M N and Bhoumik NC (2015), Study of hydrochemistry and pollution status of the Buriganga river, Bangladesh, Bangladesh Journal of Scientific and Industrial Research $\quad \mathbf{5 0}(2)$ : $123-134$. DOI:10.1016/j.wri.2016.12.003 
Sarkar M, Islam JB and Akter S (2016), Pollution and ecological risk assessment for the environmentally impacted Turag River, Bangladesh. Journal of Materials and Environmental Science 7(7): 2295-2304.

Sarkar M, Rahman AKML and Bhoumik NC (2017), Remediation of chromium and copper on water hyacinth (E. crassipes) shoot powder, Water Resources and Industry 17: 1-6.

Weyer PJ, Cerhan JR, Kross BC, Hallberg GR, Kantamneni J, Breuer G, Jones MP, Zheng $\mathrm{W}$ and Lynch CF (2001), Municipal drinking water nitrate level and cancer risk in older women: the Iowa Women's Health Study, Epidemiology 12(3): 327-338.

WHO (World Health Organization) 2008, Guidelines for drinking-water quality: incorporating $1^{\text {st }}$ and $2^{\text {nd }}$ addenda, Recommendations 1: 375.

Zakir HM, Sharmin S and Shikazono N (2006), Heavy metal pollution in water and sediments of Turag SSriver at Tongi area of Bangladesh, International Journal Lakes Rivers 1(1): 85-96. 